\title{
Pengaruh Kompensasi Terhadap Kinerja Pegawai PT. PLN (Persero) UP3 Manado
}

\author{
Angel Kralita Poluakan \\ Roy F. Runtuwene \\ Sofia A.P. Sambul \\ Jurusan Ilmu Administrasi Bisnis, Program Studi Administrasi Bisnis \\ Fakultas Ilmu Sosial \& Ilmu Politik, Universitas Sam Ratulangi Manado \\ Email: angelpoluakan26@gmail.com
}

\begin{abstract}
This study was conducted to determine whether there is an effect of compensation on employee performance at PT. PLN (Persero) UP3 Manado. Human resources play an important role in every company, because of that the company must be able to improve performance in the company by providing compensation in accordance with its achievements. This research is a quantitative approach, because this research is presented with numbers, starting from data collection, interpretation of the data, and the appearance of the results. In this study the population studied was 60 employees. Based on the results of a simple linear regression analysis concluded that compensation affects the performance of employees of PT. PLN (Persero) UP3 Manado. This is evidenced from the results of the hypothesis test ( $t$ test).
\end{abstract}

\section{Keywords : Compansation, Performence}

\section{PENDAHULUAN}

PT. PLN (Persero) merupakan salah satu Badan Usaha Milik Negara yang berperan sebagai penyedia tenaga listrik yang sangat dibutuhkan oleh masyarakat. Meskipun fungsi legulator dibidang ketenagalistrikan merupakan tugas dan tanggung jawab pemerintah daerah, PT PLN (Persero) sebagai perpanjangan tangan dari pemerintah tetap diberi prioritas pertama dalam penyediaan tenaga listrik untuk umum. Sebagai salah satu BUMN yang memegang peranan penting, secara tidak langsung perusahaan ini mengalami penumpukkan dalam ruang lingkup pekerjaannya. Ruang lingkup tersebut meliputi usaha penyedia tenaga listrik, usaha penunjang tenaga listrik dan usaha lain yang menyangkut kegiatan operasional. Dengan begitu banyak lingkup pekerjaan, PT PLN Persero membutuhkan Sumber Daya Manusia yang berkualitas serta para teknisi dilapangan yang berkompetisi dibidangnya. Sumber Daya Manusia memegang peranan yang sangat penting dalam setiap perusahaan, karena di tangan merekalah kelangsungan hidup perusahaan bergantung.Oleh karena 
ituperusahaan di tuntut untuk memiliki kualitas dan kuantitas Sumber Daya Manusia yang memadai, dalam hal ini pegawai yang handal dengan skill yang berkualitas sesuai dengan bidang yang ada di perusahaan. Berdasarkan latar belakang masalah yang telah dikemukakan di atas, maka permasalahan yang akan dikaji dalam penelitian ini adalah apakah kompensasi mempunyai pengaruh terhadap kinerja pegawai pada PT PLN (Persero) UP3 Manado.

\section{LANDASAN TEORI}

\section{Definisi Kompensasi}

1. Menurut Sihotang $(2007: 220)$ Kompensasi adalah pengaturan keseluruhan pembrian balas jasa bagi pegawai dan para manajer baik berupa finansial maupun barang dan jasa pelayanan yang diterima oleh setiap orang karyawan.

2. Menurut Skula dalam Mangkunegara (2007:83) Kompensasi merupakan sesuatu yang dipertimbangkan sebagai sesuatu yang sebanding. Dalam kepegawaian, hadiah yang bersifat uang merupakan kompensasi yang diberikan kepada pegawai sebagai penghargaan dari pelayanan mereka.

\section{Fungsi Kompensasi}

Menurut pendapat Susilo Martoyo (1990:100), fungsi-fungsi pemberian kompensasi.

1. Pengalokasian Sumber Daya Manusia Secara Efisien.

Fungsi ini menunjukkan bahwa pemberian kompensasi yang cukup baik pada karyawan berprestasi baik, akan mendorong para karyawan untuk bekerja dengan lebih baik dan ke arah pekerjaan-pekerjaan yang lebih produktif. Dengan kata lain, ada kecendrungan para karyawan yang bergeser atau berpindah dari yang kompensasinya rendah ke tempat kerja yang kompensasinya tinggi dengan cara menunjukkan prestasi kerja yang lebih baik.

2. Penggunaan Sumber Daya Manusia Yang Efisien dan Efektif.

Dengan pemberian kompensasi yang tinggi kepada seorang pegawai mengandung keterkaitan bahwa organisasi akan memanfaatkan tenaga pegawai termasuk dengan seefisien dan seefektif mungkin. Kareana dengan aturan begitu, organisasi berhubungan akan mencapai manfaat atau profit semkasimal mungkin. Disinilah produktifitas pegawai amat sangat menentukan. 
3. Mendorong Kemantapan dan Kemajuan Ekonomi

Sebagai dampak distribusi dan penggunanaan sumber daya manusia dalam organisasi yang berhubungan secara efisien dan efektif tersebut, sehingga sanggup diharapkan bahwa sistem pemberian kompensasi itu secara langsung dapat membantu kemantapan organisasi, dan secara tidak langsung turut berkontribusi dalam mendorong kemantapan dan kemajuan ekonomi negara secara totalitas.

\section{Tujuan Kompensasi}

Menurut Rivai (2004:359) tujuan kompensasi yaitu :

1. Memperoleh SDM yang berkualitas

2. Mempertahankan karyawan yang ada.

3. Menjamin keadilan

4. Penghargaan terhadap perilaku yang diinginkan

5. Mengendalikan biaya

6. Mengikuti aturan hukum

7. Memfasilitasi pengertian

8. Meningkatkan efisiensi administrasi

\section{Indikator Kompensasi}

1. Upah dan gaji

2. Insentif

3. Tunjangan

4. Fasilitas
Faktor-faktor Yang Mempengaruhi Kompensasi

1. Faktor pemerintah

2. Penawaran bersama antara perusahaan dan pegawai

3. Standar biaya hidup pegawai

4. Ukuran perbandingan upah

5. Permintaan dan persediaan

6. Kemampuan membayar

\section{Pengertian Kinerja}

1. Menurut Rivai dan Basri (2005) kinerja adalah kesediaan seseorang atau kelompok orang yang melakukan suatu kegiatan dan menyempurnakan sesuai dengan tanggung jawab dengan hasil seperti yang diharapkan.

\section{Kinerja Pegawai}

Pada dasarnya seorang pegawai dalam melaksanakan tugas yang dibebankan kepadanya diharapkan menunjukkan suatu kinerja yang terbaik yang bisa ditunjukkan oleh pegawai tersebut, selain itu kinerja yang ditunjukan oleh seorang pegawai tentu saja dipengaruhi oleh berbagai faktor yang penting artinya bagi peningkatan hasil kerja yang menjadi tujuan organisasi atau instansi dimana pegawai tersebut bekerja.

\section{Tujuan Kinerja Pegawai}

Adapun tujuan kinerja pegawai menurut Rivai (2009 :549): 
kerja sehari-hari dalam mencapai tujuan organisasi.

2. Faktor lingkungan organisasi

Faktor lingkungan kerja organisasi sangat menunjang bagi individu dalam mencapai prestasi kerja. Faktor lingkungan organisasi yang dimaksud antara lain uraian jabatan yang jelas, autoritas yang memadai, target kerja yang menantang, pola komunikasi kerja efektif, hubungan kerja harmonis, iklim kerja respek dan dinamis, peluang berkarier dan fasilitas kerja yang relatif memadai.

\section{Faktor Yang Mempengaruhi Pencapaian}

\section{Kinerja}

Faktor-faktor penentu pencapaian prestasi kerja atau kinerja individu dalam organisasi menurut A.A. Anwar Prabu Mangkunegara (2005:16-17) adalah sebagai berikut:

1. Faktor individu

Secara psikologis, individu yang normal adalah individuyang memiliki integritas yang tinggi antara fungsi psikis (rohani) dan fisiknya (jasmaniah). Dengan adanya integritas yang tinggi antara fungsi psikis dan fisik, maka individu tersebut memiliki konsentrasi diri yang baik. Konsentrasi yang baik ini merupakan modal utama individu manusia untuk mampu mengelola dan mendayagunakan potensi dirinya secara optimal dalam melaksanakan kegiatan atau aktivitas

\section{Pengukuran Kinerja Pegawai}

Ada beberapa pengukuran kinerja yaitu menurut Robbins(2006:26 adalah sebagai berikut:

a. Kualitas. Kualitas diukur dari persepsi karyawan terhadap kualitas pekerjaan serta kesempurnaan juga terhadap ketrampilan dan kemampuan karyawan.

b. Kuantitas. Merupakan jumlah uang dihasilkan dinyatakan dalam istilah seperti jumlah unit, jumlah siklus aktivitas yang diselesaikan.

c. Ketetapan waktu. Merupakan tingkat aktivitas diselesaikan pada awal waktu yang dinyatakan. Dilihat dari sudut koordinasi dengan hasil output serta 
memaksimalkan waktu yang tersedia untuk aktivitas lain.

d. Tanggung jawab. Merupakan suatu tingkat dimana karyawan mempunyai komitmen kerja dengan instansi dan tanggung jawab karyawan terhadap kantor.

\section{Hipotesis}

Berdasarkan latar belakang dan masalah pokok maka yang menjadi hipotesis penulis adalah diduga kompensasi berpengaruh positif terhadap kinerja pegawai PT PLN (Persero) UP3 Manado.

\section{METODE PENELITIAN}

Pendekatan penelitian ini adalah pendekatan kuantitatif, karena penelitian ini disajikan dengan angka-angka. Hal ini sesuai dengan pendapat (Arikunto 2006 :12) yang mengemukakan penelitian kuantitatif adalah pendekatan penelitian yang banyak dituntut menggunakan angka, mulai dari pengumpulan data, penafsiran terhadap data tersebut, serta penampilan hasilnya.

\section{Subjek dan Objek Penelitian}

1. Subjek Penelitian

Subyek Penelitian ini dilakukan kepada para karyawan yang bekerja di PT PLN (Persero) UP3 Manado.

2. Objek Penelitian
Objek penelitian adalah kompensasi dan kinerja pegawai.

\section{Waktu dan Lokasi Penelitian}

1. Waktu penelitian

Penelitian ini dilakukan pada Februari Maret 2019

2. Lokasi penelitian

PT PLN (Persero) UP3 Manado, Sulawesi Utara.

\section{Sumber Data}

a. Data Primer

Data primer adalah data yang dikumpulkan secara langsung darisumbernya yaitu pegawai PT PLN (Persero) UP3 Manado.

b. Data Sekunder

Data sekunder adalah data yang tidak langsung diperoleh dengan mencari atau mengumpulkan dokumen-dokumen serta literatur yang mempunyai kaitan dengan masalah kompensasi.

\section{HASIL PENELITIAN}

Berdasarkan data jenis kelamin responden yang diperoleh, dapat dilihat bahwa responden laki - laki dengan presentase $72 \%$ responden laki-laki lebih banyak dari responden perempuan yaitu $28 \%$. Berdasarkan usia, responden yang dengan usia 21 - 29 menempati nilai tertinggi dengan presentase $58 \%$ dan yang terkecil adalah usia $<20$ dengan presentase 
5\%. Berdasarkan pendidikan responden, karyawan mayoritas berpendidikan SMA yaitu sebanyak 23 orang atau dengan presentase $38 \%$ dan yang terkecil adalah yang berpendidikan D1yaitu sebanyak 3 orang dengan presentase 5\%. Hasil penelitian juga menunjukkan, berdasarkan status kerja, responden yang diperoleh penulis mayoritas adalah pegawai tetap 44 orang dengan presentase $73 \%$.

Hasil penelitian analisis deskriptif secara umum menunjukkan hasil keseluruhan rata-rata variabel kompensasi yaitu 4.00. angka ini menunjukkan bahwa kompensasi termasuk dalam kategori cukup tinggi yang artinya kompensasi yang diberikan PT PLN (Persero) UP3 Manado termasuk dalam kompensasi sudah sesuai/layak. Jika dilihat dari rata-rata skor setiap item pertanyaan skor indicator tertinggi adalah pada pertanyaan nomor 4 menngenai asuransi dengan skor 4,35 yang artinya pemberian asuransi selalu menjadi bagian penting bagi kesejahteraan pegawai dan perusahaan. Sedangkan skor terendah pada item pertanyaan nomor 2 yaitu insentif dengan skor 3.9 yang artinya perusahaan harus memperhatikan atau membenahi kebijakan mengenai pemberian insentif yang diberikan kepada pegawai agar terciptanya kesuksesan bersama.

Hasil penelitian analisis deskriptif secara keseluruhan rata-rata variabel kinerja yaitu 4.18 yang termasuk dalam kategori cukup tinggi yang berarti bahwa pegawai yang bekerja di PT PLN (Persero) UP3 Manado ini mampu bekerja dengan baik. Jika dilihat dari rata-rata skor tertinggi adalah pertanyaan nomor 5 tentang tanggung jawab dengan skor 4.33 yang artinya pegawai sudah memiliki kesadaran akan tanggung jawab terhadap tugas yang telah diberikan/ditetapkan perusahaan. Kemudian butir pertanyaan dengan rata-rata skor terendah yaitu pertanyaan nomor 2 mengenai indikator kuantitas dengan skor 4.05. Namun dalam penelitian ini masih termasuk dalam kategori cukup tinggi yang namun masih perlu ditingkatkan lagi.

Berdasarkan hasil analisis regresi linear sederhana disimpulkan bahwa kompensasi berpengaruh terhadap kinerja. Hal ini dibuktikan dari hasil uji hipotesis (Uji t) $2.529>2.002$. Pengaruh kompensasi ini bersifat positif dan nilai signifikan (0.027) lebih kecil dari 0.05 artinya apabila pemberian kompensasi perusahaan semakin baik, maka hal tersebut akan mendorong pegawai untuk meningkatkan kinerja demi kemajuan perusahaan menjadi lebih baik.

\section{PEMBAHASAN}

Kompensasi adalah imbalan yang diberikan perusahaan kepada pegawai, karena pegawai tersebut telah memberikan 
sumbangan pikiran demi kemajuan perusahaan dalam rangka mencapai tujuan yang telah ditetapkan, baik dalam jangka waktu panjang maupun pendek dengan adanya pemberian kompensasi berupa gaji, insentif, tunjangan dan fasilitas maka kinerja pegawai akan semakin meningkat dan melaksanakan tugas dengan sungguhsungguh dan profesional. Kompensasi menjadi faktor yang sangat penting dalam meningkatkan kinerja pegawai karena dengan adanya kompensasi pegawai semakin bersemangat dalam bekerja untuk kemajuan perusahaan. Semakin besar kompensasi yang diberikan perusahaan maka semakin tinggi usaha pegawai dalam meningkatkan kinerja perusahaan, begitupun sebaliknya. Berdasarkan hasil penelitian menunjukkan, kompensasi berpengaruh positif dan signifikan terhadap kinerja. Hasil ini menunjukkan bahwa dengan kebijakan pemberian kompensasi yang adil kepada pegawai PT. PLN (Persero) UP3 Manado. Hasil penelitian menunjukkan kompensasi berpengaruh positif terhadap kinerja pegawai.

\section{Simpulan}

Kesimpulan yang dapat disampaikan berdasarkan hasil penelitian pada pegawai PT PLN (Persero) UP3 Manado dan analisis yang telah dikemukakan pada bab sebelumnya yang diperoleh bahwa penelitian ini mendukung hipotesis yang diajukan yaitu terdapat pengaruh kompensasi terhadap kinerja pegawai PT. PT PLN (Persero) UP3 Manado.

1. Kompensasi dan kinerja pegawai PT.PLN (Persero) UP3Manado termasuk dalam kategori cukup tinggi. Hal ini berarti kompensasi yang diterima sesuai dengan yang diharapkan oleh pegawai, dan pegawai dalam bekerja sudah sesuai dengan kualitas, kuantitas, ketepatan waktu, ketelitian dan tanggung jawab yang perusahaan inginkan.

2. Berdasarkan hasil analisis regresi sederhana disimpulkan bahwa kompensasi berpengaruh positif dan signifikan terhadap kinerja pegawai pada PT. PLN (Persero) UP3 Manado. Hal tersebut berarti semakin tinggi kompensasi yang diberikan, maka akan semakin tinggi pula kinerja pegawai.

Saran yang dapat diberikan melalui penelitian ini adalah sebagai berikut:

1. Perusahaan hendaknya senantiasa meninjau pemberian kompensasi yang layak bagi pegawai sehingga pegawai dapat terdorong untuk melaksanakan tugas dengan baik.

2. Variabel dalam penelitian ini hanya bersifat mewakili dan tidak menilai secara keseluruhan. Maka disarankan 
agar perusahaan mengevaluasi variabel

lain yang dinilai mampu untuk

meningkatkan kinerja pegawai.
Viani, Catur. 2015. Pengaruh Kompensasi Terhadap Kinerja Karyawan (Studi Kasus di BMT Bina Instansi Pringapus

\section{DAFTAR PUSTAKA.}

Amirin, T. 2011, Populasi dan Sampel Penelitian 4: Ukuran Sampel Rumus Slovin, Erlangga, Jakarta.

Arikunto, S 2006. Proedur Penelitian Suatu Pendekatan Praktik. Jakarta: Rineka Cipta.

Mangkunegara. Anwar. Prabu. 2004. Manajemen Sumber Daya Manusia, Remaja Rosdakarya, Bandung.

Nathania, Catherine. 2016. Pengaruh Kompensasi Terhadap Kinerja Karyawan Pada PD Damai Motor Bandar Lampung.

Rivai, Veithzal, dan Sagala, Ella Jauvani. 2009. Manajemen Sumber Daya Manusia Untuk Perusahaan dari Teori ke Praktek. Jakarta. PT. Raja Grafindo.

Robbins, Stephen P. 2006. Perilaku Organisasi. Edisi kesepuluh. Jakarta: PT. Indeks Kelompok Gramedia.

Sihotang. A. 2007. Sumber Daya Manusia. Jakarta: Pradnya Paramita.

Simamora, Henry. 2004. Manajemen Sumber Daya Manusia. Yogyakarta: STIE YKPN.

Sugiyono. 2012. Metode Penelitian Bisnis. Bandung: Alfabeta. 